\title{
CONCEPTIONS OF LEARNING OF PROSPECTIVE PROFESSIONAL ACCOUNTANTS IN IRELAND: AN EXPLORATORY STUDY
}

\author{
Barbara Flood \\ Dublin City University \\ and \\ Richard M.S. Wilson \\ Loughborough University
}

\begin{abstract}
This exploratory interview-based study examines the conceptions of learning of eight students who had recently completed the qualifying examinations of one of the professional accountancy bodies in Ireland. The paper presents and analyses the participants' descriptions of what learning means to them and investigates the possibility of classifying the descriptions using categorisations of conceptions of learning established in prior research in the higher education setting. The findings reveal that both reproductive and constructive conceptions are identified among the participants and the established categories of description capture the variation in the conceptions reported.
\end{abstract}

\section{INTRODUCTION}

It is widely recognised that the role and the work environments of professional accountants are increasingly dynamic and complex and that accounting programmes must keep pace with these changes in order to educate and train future accountants appropriately (Albrecht and Sack, 2000; Deppe, Sonderegger, Stice, Clark and Streuling, 1991). Accounting education has been heavily criticised for focusing on the transmission of technical knowledge rather than on developing the wide range of knowledge and skills that students will need to maintain professional competence in the twenty-first century (American Accounting Association (AAA), 1986; Albrecht and Sack, 2000; Arthur Andersen \& Co., Arthur Young, Coopers \& Lybrand, Deloitte Haskins \& Sells, Ernst \& Whinney, Peat Marwick Mitchell, PriceWaterhouse and Touche Ross, 1989; Power, 1991; Sundem and Williams, 1992; Tinker, 1985). To prepare students for their 
professional careers, education programmes need to move from a content orientation to focusing on the process of student learning and the achievement of desirable learning outcomes. The International Federation of Accountants (IFAC), which represents 157 professional accountancy bodies worldwide, embraces the change agenda, contending that the education and practical experience of professional accountants should provide a foundation of professional knowledge, professional skills and professional values, ethics and attitudes that enable them to continue to learn and adapt to change throughout their professional lives' (IFAC, 2003, para. 9).

While the call for research to support accounting education change has generally been well-heeded, the setting for such research has commonly been within accounting programmes in higher education. This focus may be justified in the United States (US), where many students take the qualifying examinations of professional accountancy bodies while completing their higher education studies, thus experiencing pre-qualification accounting education wholly in the higher education setting. However, in Ireland and the United Kingdom (UK) those seeking to qualify with the professional accountancy bodies typically spend a number of years, after the completion of higher education programmes, preparing for the examinations of those professional bodies. At the same time, these prospective professional accountants must gain a minimum of three years' appropriate professional training to obtain their professional qualification. Thus, while it is very important to enhance and support the increasingly active field of research focusing on accounting education within higher education, there is also a need to extend the research agenda in Ireland and the UK to the pre-qualification professional accounting education environment. The present paper addresses this gap in the prior literature by exploring conceptions of learning of pre-qualification professional accounting students.

Membership of professional accountancy bodies in Ireland has expanded considerably in the past twenty years and the wide-ranging career opportunities available to accountants have attracted a large number of graduates to the profession each year (Byrne and Flood, 2003; Downes, 2007; IAASA, 2008; Riley, 2008). However, it must be recognised that the increasing opportunities for professional accountants in Ireland have given rise to many of the problems and challenges faced in the US, UK and elsewhere. The dynamic work environments and the impact of technology, for example, have emphasised the need for Irish accountants to develop new skills and competencies to help them adapt to their changing roles (Collins, 2000). A survey of members of the Institute of Chartered Accountants in Ireland (ICAI), the largest professional accounting body in Ireland, indicated that while they considered that their professional education prepared them well for the traditional accounting activities of information analysis and problem solving, it had not sufficiently developed broader knowledge and skills necessary for the current dynamic work environment (Meagher, 2001).

In recognising the need for new members to have a wide range of knowledge and skills that allow them rapidly adapt to change, the ICAI began the roll-out of 
a new competency-oriented professional education programme in 2007. The desired learning outcomes of the new pre-qualification education programme are that students will have 'a detailed comprehension of core concepts and principles and the capability to apply this comprehension along with professional judgement to the resolution of problems in an intra- and inter-disciplinary context' (ICAI, 2007, p. 66). To achieve these learning outcomes the new education programme focuses on the development of functional competencies, business competencies and core professional values (ICAI, 2007). However, while the ICAI, like many other professional accountancy bodies, has clearly articulated the goals or desired outcomes of pre-qualification professional education, there has been very little research conducted in Ireland or elsewhere to understand how students learn in the context of professional accounting programmes and to examine how both personal and situational factors impact on such learning. Without such research, it is difficult to envisage how appropriate educational design, operation and evaluation (in terms of syllabus, teaching methodologies, assessment strategies, etc.) can occur to facilitate the achievement of high quality student learning outcomes in professional accounting education.

This study provides some initial insights into student learning in the context of professional accounting education by exploring the conceptions of learning of a small group of students of one of the Irish professional accountancy bodies. As there is relatively little written about student learning within the professional accounting context, or indeed within professional education generally (Taylor, 1997), the study is informed by student learning research within the higher education setting. The authors fully acknowledge that concepts developed in the higher education context cannot be unquestionably applied to the context of pre-qualification professional education, but is seems reasonable and, indeed, sensible when developing a research agenda for the professional accounting education arena to consider the extension of these existing concepts to the new setting. Perhaps a reasonable question to ask before commencing such a study is why students in the professional accounting context merit separate examination. In other words, why would we anticipate that such students might hold different conceptions of learning to students in higher education? Flood and Wilson (2008) contend that the close interaction of professional education and practice, the variations in the learning environment (syllabus, teaching approaches, forms of assessment, etc.) and the more diverse personal factors of students (prior educational experiences, life and work experiences, etc.) result in the context and experience of professional accounting education being potentially divergent to that of higher education. Thus, the examination of learning conceptions in this previously unexplored context is a valid research objective.

The remainder of the paper is structured as follows. Firstly, prior literature concerning conceptions of learning is considered. The subsequent section presents the specific objectives of this study and describes the data collection and analysis process. The findings are then presented and discussed and the paper concludes following consideration of the implications and limitations of the study. 


\section{CONCEPTIONS OF LEARNING}

Prior to the 1970s, studies concerning student learning typically explored the quantity of what students learned from an external perspective and did not provide an understanding of why some students learned 'better' than others (Marton and Booth, 1997, pp. 14-16). The new stream of student learning research that emerged sought to understand the process of student learning from the perspective of individual students. More particularly, it began to explore the ways in which students approached learning tasks, the influence of the learning context and the variation in the learning outcomes achieved. It was repeatedly found that the quality of the learning outcome achieved, in terms of the degree of understanding abstracted or constructed, is influenced by the learning approach adopted.

A learning approach describes how a student relates to a learning task and two different learning approaches were primarily identified: a deep approach and a surface approach (Ramsden, 1987). It was found that deep approaches to learning were related to high quality learning outcomes as opposed to surface approaches, which were related to poor quality learning outcomes (Marton and Saljo, 1976a). Importantly, it was recognised that learning approaches are not intrinsic characteristics of students, rather they are dynamic and are influenced by a whole range of both personal and contextual factors (Marton and Saljo, 1976a, 1976b; Entwistle and Ramsden, 1983; Prosser and Trigwell, 1999). The significance of the learning environment, in terms of syllabus, teaching and assessment, on students' learning approaches cannot be overstated. Indeed, it is the interaction of a student's perceptions of the learning environment with personal variables that results in the student's decision to adopt a particular learning approach to a learning task. One of the many personal factors found to be related to the variation in students' learning approaches and ultimately to the quality of the learning outcomes achieved is their conceptions of learning (Dahlgren and Marton, 1978).

A conception of learning captures the way in which a person views learning, in other words, what learning means to him or her. In early work in the area Dahlgren and Marton (1978) identified two different conceptions of learning. The first conception views learning as something that is initiated externally of the individual. It is not something driven by internal motive; learning happens to the person and is conceived in this instance as a passive activity involving the transmission of unrelated 'bits of knowledge'. The second conception captures an active view of learning, which involves changing one's conception of reality in some way. Saljo (1979), developing this work further, explored the qualitative variation in the ways students described their view of learning and determined five categories of description to capture the variation identified. These five categories of description (Conceptions A-E), have subsequently been confirmed by a number of researchers, notably Van Rossum and Schenk (1984) and Van Rossum, Deijkers and Hamer (1985), while Marton, Dall'Alba and Beaty (1993) more fully described the five categories and identified a sixth (Conception F). The elements or characteristics of these various conceptions are briefly outlined in Table 1.

A conception of learning is not a stable characteristic or attribute of an individual, rather it reflects his/her current learning context and is likely to 
TABLE I: CONCEPTIONS OF LEARNING

\begin{tabular}{|c|c|}
\hline Category of Description & Characteristics \\
\hline \multicolumn{2}{|l|}{ Learning as... } \\
\hline A. An increase in knowledge & Passive, external process of accumulating knowledge \\
\hline B. Memorising & $\begin{array}{l}\text { Passive, external process of accumulating knowledge } \\
\text { but recognising that knowledge gained may be } \\
\text { reproduced on specific occasions (e.g. exams) }\end{array}$ \\
\hline $\begin{array}{l}\text { C. Acquisition of facts that can be } \\
\text { retained and/or used in practice }\end{array}$ & $\begin{array}{l}\text { Passive, external process of accumulation but } \\
\text { focused on the application of knowledge and } \\
\text { recognising that acquired knowledge may need to } \\
\text { be tailored or adjusted for application in practice }\end{array}$ \\
\hline D. Abstraction of meaning & $\begin{array}{l}\text { Active, intrinsic process focused on developing } \\
\text { personal understanding }\end{array}$ \\
\hline $\begin{array}{l}\text { E. Interpretive process aimed } \\
\text { at understanding reality }\end{array}$ & $\begin{array}{l}\text { Active, intrinsic process focused on developing } \\
\text { personal understanding and then confirming } \\
\text { and/or changing one's view of a phenomenon as a } \\
\text { result of that understanding }\end{array}$ \\
\hline F. Changing as a person & $\begin{array}{l}\text { Active, intrinsic process focused on developing } \\
\text { personal understanding and then confirming } \\
\text { and/or changing one's view of a phenomenon as a } \\
\text { result of that understanding. Through seeing the } \\
\text { world differently, learning results in changing as a } \\
\text { person }\end{array}$ \\
\hline
\end{tabular}

Source: Marton et al. (1993); Saljo (1979); Van Rossum and Schenk (1984); Van Rossum et al. (1985).

change over time as his/her learning situation changes. Indeed, Van Rossum et al. (1985) contend that the six categories of description could be viewed as a hierarchy which 'show the development of the student from novice to expert in learning (see Van Rossum and Hamer, 1985); a development that moreover is strongly contextually determined' (Van Rossum et al., 1985, pp. 636-637). In other words, it might be expected that as students mature and experience new learning situations and contexts, their conceptions of learning would become more constructivist in orientation. Indeed, such a development trend was reported among students interviewed repeatedly over a number of years in the Marton et al. (1993) study.

However, more recently, it has been recognised that the identified conceptions are not necessarily hierarchical or indeed universal, particularly when examined with non-Western students. Makoe, Richardson and Price (2008) highlight the work of Watkins and Regmi (1992), who reported that while some Nepalese students described learning as changing as a person, this was a view induced by local religious and cultural traditions and was not the most sophisticated conception described among participants. Similarly, Marton, Dall'Alba and Tse (1996) found among Chinese teacher educators that memorisation, previously considered to be associated with a low-level, reproductive conception of learning, was often associated with developing and retaining deep understanding. Makoe 
et al. state that 'there is a clear suggestion that students' conceptions of learning vary across different cultures and systems of higher education' $(2008, p .306)$ and thus the importance of examining conceptions of learning with an understanding of the learning context is reiterated.

In terms of the links between conceptions of learning and learning approaches, it is important to note the clear demarcation between Conceptions A-C and Conceptions D-F. Conceptions A-C can be grouped as reproductive(quantitative) oriented conceptions, as opposed to Conceptions D-F, which have the construction of meaning (qualitative) at their core (Duarte, 2007). Marton and Booth (1997) suggest that those who view learning primarily as reproductive limit themselves to the tasks of learning imposed by a study situation. Conversely, those who conceive learning in the constructive terms of seeking meaning look beyond the tasks themselves to the world that the tasks reveal. They conclude that 'this is directly analogous to the difference between surface and deep approaches to learning: the former focusing on the tasks themselves and the latter going beyond the tasks to what the tasks signify' (Marton and Booth, 1997, p. 38, emphasis in original). Indeed, Van Rossum and Schenk (1984) found that students who held reproductive conceptions of learning adopted surface approaches to learning, whereas those who adopted constructive conceptions adopted deep approaches to learning. Thus, if educators are interested in encouraging deep approaches to learning so that high quality learning outcomes might emerge, then fostering constructive views of the nature of learning is required.

There has been very limited examination of the conceptions of learning of accounting students at any level or in any context. A study by Sharma (1997) explored the views held by second-year undergraduate accounting students in Australia. He reported that the majority of students held reproductive conceptions and additionally tended to adopt surface approaches to learning. He found that students reported high levels of syllabus-boundedness and fear of failure, and preferred organised and fact-oriented courses. In a study of undergraduate and postgraduate accounting students in Ireland, Byrne and Flood (2004) reported that while evidence of all six categories of learning were found, reproductive conceptions were more prevalent that constructive conceptions. No research has been published to date that has explored the conceptions of learning of students of professional accountancy bodies.

\section{RESEARCH METHOD}

This study is exploratory in nature and its primary objective is to examine the conceptions of learning of a small group of students who had recently taken the final examinations of one of the professional accountancy bodies in Ireland. The study also aims to examine the extent to which the categories of description regarding learning conceptions identified in the higher education environment are appropriate to differentiate the conceptions of learning of the participating students in this professional education context. 
The data for the study were gathered from a series of in-depth interviews conducted with eight students who had recently taken the final qualifying examination of the body. All of the participants were working in accounting firms to complete the training requirements for membership of the professional body. In identifying participants for the study, efforts were made to capture some of the diversity of the student group, in terms of prior educational background (e.g. they are not all graduates of the same university), employer type, geographical location and gender, though in no way was the group of participants intended to be representative of the population of professional accounting students. (As a consequence, the research study and its findings are largely exploratory.) The purpose of the study was clearly outlined to the participants and they were reassured that the data would only be used for research purposes. To protect the anonymity of the participants, they were each allocated a pseudonym. A brief profile of the participating students is provided in Table 2.

The approach to the interviews was naturalistic in orientation and a general interview guide was used (Patton, 2002, p. 343). All of the interviews, with the permission of the participants, were taped and were then transcribed. The data were analysed using 'template analysis' (Crabtree and Miller, 1992). This analytical approach is widely used in qualitative research and is more flexible than many other analytical tools (King, 1998, pp. 118-119). The data were read carefully many times and each issue raised was annotated in the margin. In addition, the audiotapes were listed to repeatedly, in order to make every effort to capture the meaning of students' descriptions. In assigning labels or codes to students' descriptions of their learning conceptions, the researchers were mindful of the categories of description identified by Saljo (1979) and Marton et al. (1993), which are outlined in Table 1. If it was considered that one of the established categories of

TABLE 2: PROFILE OF PARTICIPANTS

\begin{tabular}{|c|c|c|c|}
\hline Participant* & $\begin{array}{l}\text { Higher Education } \\
\text { Degree(s) }\end{array}$ & Employment & Location \\
\hline Lucy & Accounting degree & Small firm & Dublin \\
\hline Mary & None & $\begin{array}{l}\text { Big } 4 \text { firm - } \\
\text { regional office }\end{array}$ & County town \\
\hline Anna & Finance degree & $\begin{array}{l}\text { Medium-sized } \\
\text { firm }\end{array}$ & Belfast \\
\hline Tom & $\begin{array}{l}\text { Arts degree and postgraduate } \\
\text { conversion diploma }\end{array}$ & Big 4 firm & Dublin \\
\hline Ben & $\begin{array}{l}\text { Accounting degree and Master } \\
\text { of Accounting }\end{array}$ & Medium firm & Belfast \\
\hline Rory & $\begin{array}{l}\text { Business degree and Master } \\
\text { of Accounting }\end{array}$ & Big 4 firm & Dublin \\
\hline Liam & Business degree & Small firm & County town \\
\hline Jack & Accounting degree & Big 4 firm & Dublin \\
\hline
\end{tabular}

* To maintain anonymity, the real names of the participants are not used. The names assigned are only for the purposes of clarity of discussion. 
description adequately captured the meaning of the participants' descriptions, that category label was used in this analysis. However, while existing categories were evaluated for this context and subsequently used, the researchers were also anxious to remain open to identify novel features that perhaps had not been identified among students in studies of the higher education environment. As identified in prior research, students' descriptions rarely include all aspects of a particular conception, rather they will include fragments of that conception. Hence, the aim of the analysis process in studies exploring conceptions of learning 'is to determine precisely just what the fragments are fragments of' (Marton et al., 1993, p. 285).

\section{FINDINGS AND DISCUSSION}

The presentation of the findings of this study is primarily via the explication of students' descriptions, as Marton and Booth (1997) contend 'the most revealing way of introducing the conceptions is through the way they are voiced' (p. 36). At the outset of each interview, the student was asked, 'What does learning mean to you?' The findings are presented by firstly describing the conceptions that are considered reproductive in orientation, followed by those that are constructivist in perspective. Further analysis is then conducted to determine if variation within the description of those two clusters aligns with the six categories of descriptions determined by Saljo (1979) and Marton et al. (1993).

\section{Reproductive-Oriented Conceptions}

Firstly, Lucy explains that she has always viewed her participation in educational programmes as necessary and functional, as she simply wants to acquire qualifications: 'I'm just looking forward to the day I can say "I'm an Accountant"'. Her functionalist view of education and her lack of reflection on learning results in her describing a quite simplistic view of learning:

[Learning is,] basically, broadening your knowledge ... increasing your awareness of different topics. [Lucy]

Lucy explains that she doesn't view understanding as critical to her study activities, rather she feels that understanding is developed when knowledge is put into practice in the workplace. However, she found that many aspects of the syllabus for the final qualifying examination related to issues arising in large companies, which she found were irrelevant to her work experiences with small businesses. Thus, she reflects that there is little interaction between her study activities and her training.

Liam, like Lucy, works in a small firm, and doesn't view his study activities as interacting with his work experiences. In terms of his conception of learning, he contends: 
My personal opinion is you get stuff and you go through it from start to finish and you make summaries and you learn it off and you try and understand it obviously, but I always approached new things - learned it off and then you always have it. [Liam]

While Liam acknowledges that gaining understanding is an element of learning, it is not one on which he places emphasis. He views the memorisation of new knowledge as more important as he will then 'have it' for examinations. Mary, a third student, similarly sees learning as the acquisition of knowledge for the very specific purpose of taking examinations; indeed, she describes learning as 'cramming'.

The descriptions of learning put forward by these three students (Lucy, Liam and Mary) are primarily reproductive in orientation. There is also a sense from these descriptions that learning is seen as a mechanical process that is activated when required. There is little evidence to indicate that Lucy, Liam or Mary perceives learning as personal, interesting or engaging. Mary explains that her views of learning are all filtered through the lens of studying accounting, which she has found difficult over the years and was not her first choice of study. That said, when asked to reflect on the meaning of learning in a broader context than accounting, she still relates learning to preparedness for examinations. Lucy too has had doubts about her choice of career. She really wants to gain the professional qualification because it would signify the achievement of a long-held ambition, but if she was choosing a career again she feels that she would select something else. Liam expresses uncertainty regarding how to study for aspects of the final examination. While colleagues and friends have advised him to focus on understanding knowledge and applying it in case studies, his preference is to rote-learn as this approach has proved successful for him in the past.

While Tom also views learning as the acquisition of knowledge, he considers that the application of knowledge is an integral part of learning too:

Learning would be to increase my knowledge and then to be able to apply that knowledge to whatever field is relevant, whether it be work or ... education or ... whatever. [Tom]

While Liam and Mary indicated a limited application of their 'learned' knowledge in examinations, Tom sees opportunities for the application of knowledge in a wider context. However, when he elaborates on his conception it is evident that he does not associate learning with personal interest but rather sees learning as purposeful. In particular, he associates learning with formal education and he learns in order to get marks in examinations. Additionally, Tom looks for external validation that he has learned something, rather than expressing a personal experience of learning:

I didn't do an accounting degree ... I did history, so it was essay based - so I suppose the only way you knew you were learning was when you got your essay back and it was a good mark, so you obviously impressed upon the marker that you knew what you were talking about. And then I suppose a step up, in the exam you 
Flood \& Wilson

might have a similar topic, or be able to apply some of the knowledge ... and again the marks would reflect that. [Tom]

Tom considers that understanding knowledge is a crucial element in learning, but again this view is shaped by his focus on examinations. It appears that he sees understanding not as something that gives personal meaning to learning, but rather it is necessary to ensure examination success, as he comments: 'you can learn something without understanding it, but, I mean, you would be caught out eventually'.

\section{Constructive-Oriented Conceptions}

Anna also conceives learning in terms of acquiring and applying knowledge. However, in contrast to any of the students mentioned so far, she identifies two types of knowledge as being associated with what she calls 'professional learning': technical knowledge and practical knowledge. In many ways, this distinction reflects the dual aspects of 'knowing that' and 'knowing how' associated with professional competence (Eraut, 1992, p. 105). While Anna acknowledges that technical knowledge can be acquired from textbooks, she considers that the practical element of learning is very much integrated with her work experiences as a trainee accountant:

I think that for me, learning - in terms of professional learning - there are two aspects to it - there's the technical aspect and also practically, you know, how you actually prepare a set of accounts and the background to double entry, the whole basis of the thing. And I would say that as far as the nuts and bolts of the whole thing my work experience in [Firm X] is invaluable. I couldn't imagine that I would have progressed as easily or as hassle-free without working in practice .... The other half, the technical side of it, purely for me, a lot of it was just regurgitation, you know, just sitting down with your books and going through it and learning it and just regurgitating it at exams. [Anna]

Ben also associates learning with his work and concurs with Anna that it provides him with practical knowledge:

What is learning? ... Probably accumulation of knowledge would be part of it but experience as well .... To me learning theory is probably the minor part; the major part is putting it into practice and a lot of that only comes through time. [Ben]

Ben feels that his work experiences have changed his conception of learning. He acknowledges that he enjoyed being exposed to new knowledge during his university courses but that he acquired that knowledge simply to pass examinations. Now, having worked in an accounting firm for two years, he views learning as centring on gaining experience that allows him to fulfil his professional role. There is also the sense that Ben considers his experiential knowledge as dynamic and useful, which again overlaps with Anna's conception: 
There is probably a lot of stuff that you learn in college which you never ever use in a practical way, you sort of discard that as not overly important once you passed your exam. Whereas in work, everything that you learn you'll generally use it again and ... it's like it's building up experience ... you come across a thing one time and you don't know what to do with it, so you go and find out and the next time it comes up, well you do it without even thinking about it, you know. [Ben]

Ben contends that it is possible to learn without understanding, but he would find it difficult to do so. He feels that that his experiences in work have provided him with a better foundation and framework to understand accounting and that his practical knowledge has given meaning to technical knowledge he learned in university:

It is possible to learn without understanding, but to me it's important that you understand, I find it much more difficult to learn without understanding. I would say that throughout my whole accountancy degree, Master's, right through, I never really understood accountancy until I worked in practice, you know. I learnt the FRSs back to front and inside out, and even double entry, it sounds ridiculous, but double entry never clicked until I was actually ... we did a sort of book-keeping course the first two weeks we came into [Firm Y] and it was like it was easy after that, and I was going 'if I'd known that before I'd done all those degrees' (laughing). [Ben]

Ben's conception of learning is experiential and is personal to the extent that, by learning from experience, his understanding of issues is developed and he can carry out his professional duties appropriately. Anna and Ben's emphasis on the enhancement of understanding through practice echoes the old Chinese proverb: I hear and I forget; I see and I remember; I do and I understand.

Jack's conception of learning also embraces personal engagement but it is more abstract than experiential. For Jack, learning is about having a well-developed personal understanding of concepts and topics and being able to integrate knowledge:

I think the term 'learning' is more to do with understanding topics and the grasping of concepts. I like to think from the ground level and develop my understanding of a certain concept and that's my idea of learning ... separate components and building it all together. [Jack]

There is a sense that Jack internalises learning, he charges himself with the responsibility of developing his understanding and he actively engages in his learning to gain the type of integration of knowledge from different sources that he thinks epitomises learning.

Rory similarly views learning as something very personal and something that he controls and benefits from. He contends that, for him, 'the essential point [about learning] would boil down to self-development'. He considers himself to be constantly learning and developing in every aspect of his life and effectively re-evaluating his belief system: 


\begin{abstract}
I mean, I would be one of these people that would have a belief whereby, you know, I would be very confident about what I think but I'm always open to what other people are saying ... I'd be saying 'Okay now, am I right?', take in what other people are saying, make up my own mind as opposed to being told what I'm meant to be thinking. But if you'd sort of seen me two years ago I probably would have been more bloodyminded, to pardon the expression. I probably would have just put the blinkers on: 'I'm right, I'm right, I'm right'. So once again, to a certain extent, that's development, learning what other people's skills are and learning what they have to say as well. [Rory]
\end{abstract}

Rory internalises learning. He has thought about his beliefs and why he holds those beliefs, but he does not stagnate in that position. He is open to new ideas and ways of thinking, but he doesn't simply adopt those new ideas, he evaluates them, and makes sense of them relative to his own established belief system. Also, Rory's conception of learning is highly abstract: he does not relate learning to accounting subject matter and examinations, rather it is about who he is as a person and how he develops as a person.

\title{
Application of the Six Prior Categories of Description
}

Having explored the variation in the conception of learning of the students in this study, the appropriateness of classifying these conceptions using the categories of descriptions of Saljo (1979) and Marton et al. (1993) can be considered. As illustrated in Table 1 and discussed earlier, those categories of description capture considerable variation in conceptions of learning. Further, while they were developed with students in the higher education sector, they may adequately embrace the variation of the conceptions described by participants in this study in the environment of professional accounting education. To evaluate the appropriateness of applying the established categories of description in this context, the descriptions of each of the students are considered in the light of the various categories described in Table 1. Furthermore, differences in these descriptions and those reported in prior studies in the higher education setting are evaluated.

Firstly, the reproductive-oriented descriptions of Liam, Lucy, Mary and Tom will be considered. In relation to the categories derived by Saljo (1979) and Marton et al. (1993), Lucy's description appears to fall into the category of Conception A - Learning as acquiring knowledge. The vagueness often associated with this conception is evident in her description, as she views learning as simply increasing her awareness of different topics. Her description is also very impersonal and lacks any sense of engagement. Liam's description shares many similarities to Lucy's as it focuses on the quantification and acquisition of new knowledge. However, the principal feature of his description is memorisation. While Liam implies that he will use his acquired knowledge in examinations, Mary's description explicitly focuses on this aspect. She accumulates knowledge by cramming, solely for the purpose of dealing with examinations. The rote-learning orientation of both Liam and Mary's descriptions and their acknowledgement of such a limited application of knowledge is characteristic of Conception B - Learning as memorising. 
Categorising Tom's conception of learning is a bit more complicated. Tom contends that seeking meaning in his study is important, which at the outset might imply that his conception of learning would fall into one of the constructive categories. However, it appears that although he seeks meaning it is not to gain personal understanding, rather it is to apply his knowledge appropriately in an examination or a work situation. Additionally, he doesn't describe learning in a personal way; he views it as functional and external to himself. His lack of personal involvement or internalising of learning, in addition to his focus on knowledge application, means that his description appears to be adequately described by Conception C - Learning as the acquisition of facts that can be used in practice.

What distinguishes the conceptions of learning of the four remaining students is that they conceive learning as personal, they engage with learning tasks and situations and they are more reflective of what learning means to them. As with the students describing the reproductive conceptions, no student describes every aspect of a particular category. Rather, as reported in Marton et al. (1993), students generally describe different fragments of a conception. This is particularly true in the case of the three students (Anna, Ben and Jack) whose descriptions fall into the category Conception D - Learning as the abstraction of meaning.

In the first instance, Anna's description has some similarities with Tom's. However, what pushes her description into the Conception D category is the sense that she engages personally in her learning. She reflects that her learning through work provides her with understanding of concepts and practices and she finds this learning more engaging than reproductive forms of learning. Anna's identification of different types of learning indicates how the context of learning has influenced her conception, as her view of learning has developed as a result of her exposure to accounting practice during her training.

Ben's conception of learning is similar to Anna's and he also describes a development in his views since he moved into the professional education context. He describes how his conceptualisation of learning has changed from a reproductive knowledge acquisition focus when at university to a conception that focuses on personal understanding, facilitating his professional competence. While there is a sense that Ben now sees learning as a form of personal development, this development relates to work situations only. His descriptions lack any reference to developing in terms of seeing the world differently, which would typically characterise the two higher level conceptions.

Jack's conception of learning is also very much that of Conception D. However, unlike Anna and Ben, Jack doesn't necessarily describe learning in terms of examinations or work experience, rather there is a sense that seeking meaning of material is important in itself for Jack. He likes to build strong foundations for his knowledge base and he constantly seeks interconnections in his learning. Like Anna and Ben, he actively engages in learning and his descriptions emanate from a sense of interest and involvement in his learning.

Rory's conception of learning appears to be that of developing as a person and thus appears to fall within the category identified by Marton et al. (1993): Conception F - Learning as changing as a person. Rory views personal development 
Flood \& Wilson

TABLE 3: CLASSIFICATION OF PARTICIPANTS' LEARNING CONCEPTIONS

\begin{tabular}{lll}
\hline CONCEPTION & DESCRIPTION & STUDENTS \\
\hline A. & Learning as an increase in knowledge & Lucy \\
B. & $\begin{array}{l}\text { Learning as memorisation } \\
\text { Learning as the acquisition of facts that } \\
\text { c. }\end{array}$ & Liam, Me used in practice \\
D. & $\begin{array}{l}\text { Learning as the abstraction of meaning } \\
\text { Learning as an interpretative process }\end{array}$ & Anna, Ben, Jack \\
E. & $\begin{array}{l}\text { aimed at understanding reality } \\
\text { Learning as changing as a person }\end{array}$ & Rory \\
F. & & \\
\hline
\end{tabular}

as the essence of learning, it involves him seeing things differently, and reflecting on and changing his personal beliefs. Another characteristic of this conception that Rory embraces is that learning is not restricted to specific aspects of his life, rather he sees it as enveloping every part of his existence. Rory's conception is the most complex and most developed of the participants in this study. The classification of the conceptions of learning of the participants in this study to the various categories identified in the prior literature is summarised in Table 3.

\section{CONTRIBUTION, IMPLICATIONS AND LIMITATIONS}

It has been found that the previously reported categories of description identified in the higher education setting appropriately reflected the variation in the conceptions of learning described by the participants in this study. The clear distinction between Conceptions A-C and Conceptions D-F reported in prior studies was evident and clearly centred on whether learning embraced understanding and the extent to which students engaged with, and were active in, their learning. Thus, this study has determined the appropriateness of extending the categories of description of Saljo (1979) and Marton et al. (1993) to the conceptions of learning of this group of students in the professional accounting domain in Ireland. Furthermore, this study has expanded the literature on conceptions of learning by elaborating the characteristics that distinguish reproducing conceptions and constructive conceptions.

The students in this study who describe reproductive conceptions of learning appear to restrict the notion of learning to what is required for examination purposes and do not make any reference to learning as part of either their training in the workplace or their wider lives. On the other hand, the students describing constructive conceptions have reflected on the notion of learning in the contexts of education programmes and the workplace. While this demarcation between reproducing and constructive conceptions is very much in keeping with other characteristics that distinguish such conceptions, the findings may be useful for the interpretations of 'fragments' (Marton et al., 1993, p. 285) of descriptions of conceptions that might emerge if this type of study is conducted with other groups of students in professional education programmes. 
A further interesting insight provided by this small-scale study is the reflections of the participants concerning their experiences of both working and studying, as opposed to their prior experiences of studying full-time in higher education. Two students explicitly reflect on the maturing of their conceptions due to their changed learning environment. They contend that their professional experiences have caused them to alter their view of learning from something that is solely for examinations to that of seeing learning as something that is engaging, evolving and highly relevant to the maintenance of their professional competence. Thus, evidence is provided, albeit from a very small number of cases, of a development trend in learning conceptions.

The findings of this study may be useful in a number of ways. Firstly, while the study embraced only a small number of cases, it may enhance awareness among educators of the variation of student characteristics and perceptions in the professional accounting environment. Coupled with evidence from additional cases, such increased awareness may motivate educators in the accounting profession and more generally to reflect on the implications of the way they design and present their courses for students holding such varied conceptions of learning. Secondly, the findings may provide an impetus for further investigation of student learning issues in this environment. In particular, future research needs to explore the relationships between conceptions of learning, context variables, students' learning approaches and learning outcomes in the setting of professional accounting education. Thirdly, the study has indicated the need to examine the interplay between education programmes and the training experiences of prospective professional accountants, to ensure that they are properly integrated and develop the base level of professional competence that will act as a foundation for lifelong learning. This study and further studies in this domain may provide some evidence of the effectiveness of the pre-qualification education system within the accounting profession from the student perspective, and may generate an additional frame of reference for education reforms within professional accountancy bodies.

In terms of limitations, it is clear that this study was exploratory in nature and only gathered data from a small number of students. While care was taken to select participants with different characteristics (gender, prior education experience, type of training firm, etc.) in the hope of exposing variation in the conceptions of learning held in this context, it is possible that alternative conceptions of learning are held by students who did not participate in this study. It would be very useful if future research replicated this study in the same or similar contexts and, indeed, the work could be extended by a quantitative examination of learning conceptions of a large sample of students.

\section{CONCLUSIONS}

Higher education research has demonstrated that students' conceptions of learning influence their learning approaches and the quality of their learning outcomes. The accounting profession espouses the need for future professional accountants 
to achieve high quality learning outcomes, yet there is little evidence concerning the student learning process and the factors that influence learning approaches within the context of pre-qualification professional accounting education.

This paper explored the conceptions of learning of a small group of students who had recently completed the final qualifying examination of one of the professional accountancy bodies in Ireland. It reported that the categories of description regarding students' conceptions of learning identified in the higher education setting appear to be appropriate to capture the variation in the descriptions presented by the students in this study. Four students in the study have reproductive conceptions of learning, varying from a vague view of learning as the broadening of one's knowledge base to a more developed view of applying acquired knowledge in study and work situations. Three students, in different ways, view learning as centring on the construction of meaning, while one describes the more complex conceptualisation of learning, that of learning as changing as a person.

There is a pressing need for further research on student learning issues in the domain of professional accounting education. This type of research, which is from the perspective of the student, is necessary if the profession is serious about improving student learning approaches and learning outcomes so that future professional accountants are better prepared to deal with the challenges of their professional lives.

\section{REFERENCES}

Albrecht, W.S. and Sack, R.J. (2000). Accounting Education: Charting the Course through a Perilous Future, Sarasota, FL: American Accounting Association.

American Accounting Association (AAA) Committee on the Future Structure, Content and Scope of Accounting Education (The Bedford Committee) (1986). Future Accounting Education: Preparing for the Expanded Profession, Issues in Accounting Education, Vol. 1, No.1, pp. 168-195.

Arthur Andersen \& Co., Arthur Young, Coopers \& Lybrand, Deloitte Haskins \& Sells, Ernst \& Whinney, Peat Marwick Mitchell, PriceWaterhouse and Touche Ross (1989). Perspectives on Education: Capabilities for Success in the Accounting Profession, New York, NY: Arthur Andersen \& Co., Arthur Young, Coopers \& Lybrand, Deloitte Haskins \& Sells, Ernst \& Whinney, Peat Marwick Mitchell, PriceWaterhouse and Touche Ross.

Byrne, M. and Flood, B. (2003). Defining the Past and Shaping the Future: The Changing Nature of Accounting Education in Ireland, Journal of Accounting Education, Vol. 21, No. 3, pp. 197-213.

Byrne, M. and Flood, B. (2004). Exploring the Conceptions of Learning of Accounting Students, Accounting Education: An International Journal, Vol. 13, special issue, pp. 25-37.

Collins, A. (2000). Accountants as Custodians of Information and Knowledge, Accountancy Ireland, Vol. 32, No. 4, pp. 16-17.

Crabtree, B.F. and Miller, W.L. (1992). A Template Approach to Text Analysis: Developing and Using Codebooks, in B.F. Crabtree and W.L. Miller (eds), Doing Qualitative Research, Newbury Park, CA: Sage Publications. 
Dahlgren, L. and Marton, F. (1978). Students' Conceptions of Subject Matter: An Aspect of Learning and Teaching in Higher Education, Studies in Higher Education, Vol. 3, No. 1, pp. 25-35.

Deppe, L., Sonderegger, E., Stice, J., Clark, D. and Streuling, G. (1991). Emerging Competencies for the Practice of Accountancy, Journal of Accounting Education, Vol. 9, No. 2, pp. 257-290.

Downes, D. (2007). Incoming ICAI president, Vincent Sheridan, on Priorities for the Year Ahead, Accountancy Ireland, Vol. 39, No. 3, pp. 7-9.

Duarte (2007). Conceptions of Learning and Approaches to Learning in Portuguese Students, Higher Education, Vol. 54, No. 6, pp. 781-794.

Entwistle, N. and Ramsden, P. (1983). Understanding Student Learning, London: Croom Helm.

Eraut, M. (1992). Developing the Knowledge Base: A Process Perspective on Professional Education, in R. Barnett (ed), Learning to Effect, Buckingham: Society for Research into Higher Education (SRHE) and Open University Press.

Flood, B. and Wilson, R.M.S. (2008). An Exploration of the Learning Approaches of Prospective Professional Accountants in Ireland, Accounting Forum, Vol. 32, No. 3, pp. 225-239.

Institute of Chartered Accountants in Ireland (ICAI) (2007). ICAI Competency Statement 2007, Dublin: ICAI.

International Federation of Accountants (IFAC) (2003). Introduction to International Education Standards, New York, NY: IFAC.

Irish Auditing \& Accounting Supervisory Authority (IAASA) (2008) Annual Report 2007, Kildare: IAASA.

King, N. (1998) Template Analysis, in G. Symon and C. Cassell (eds), Qualitative Methods and Analysis in Organizational Research, London: Sage Publications.

Makoe, M., Richardson, J. and Price, L. (2008). Conceptions of Learning in Adult Students Embarking on Distance Education, Higher Education, Vol. 55, No. 3, pp. 303-320.

Marton, F. and Booth, S. (1997). Learning and Awareness, Mahwah, NJ: Lawrence Erlbaum Associates.

Marton, F., Dall' Alba, G. and Beaty, E. (1993). Conceptions of Learning, International Journal of Educational Research, Vol. 19, No. 3, pp. 277-300.

Marton, F., Dall' Alba, G. and Tse, L. (1996). Memorizing and Understanding: The Keys to the Paradox?, in D. Watkins and J. Biggs (eds), The Chinese Learning: Cultural, Psychological and Contextual Factors, Hong Kong: University of Hong Kong, Comparative Educational Research Centre; Melbourne: Australian Council for Educational Research.

Marton, F., and Saljo, R. (1976a). On Qualitative Differences in Learning: I - Outcome and Process, British Journal of Educational Psychology, Vol. 46, pp. 4-11.

Marton, F, and Saljo, R. (1976b). On Qualitative Differences in Learning: II - Outcome as a Function of the Learner's Conception of the Task, British Journal of Educational Psychology, Vol. 46, pp. 115-127.

Meagher, M. (2001). Improving Accountancy Education: The Professionals' Perspective, Accountancy Ireland, Vol. 33, No. 5, pp. 18-20.

Patton, M.Q. (2002). Qualitative Research and Evaluation Methods, Newbury Park, CA: Sage Publications.

Power, M.K. (1991). Educating Accountants: Towards a Critical Ethnography, Accounting Organizations and Society, Vol. 16, No. 4, pp. 333-353.

Prosser, M. and Trigwell, K. (1999). Understanding Learning and Teaching: The Experience of Higher Education, Buckingham: Society for Research into Higher Education and Open University Press. 
Flood \& Wilson

Ramsden, P. (1987). Improving Teaching and Learning in Higher Education: The Case for a Relational Perspective, Studies in Higher Education, Vol. 12, No. 3, pp. 275-286.

Riley, L. (2008). ICAI Examinations: Record Numbers in 2007, Accountancy Ireland, Vol. 40, No. 1, pp. 86-87.

Saljo (1979). Learning in the Learner's Perspective, Reports from the Department of Education, Goteborg University, No. 76.

Sharma, D. (1997). Accounting Students' Learning Conceptions, Approaches to Learning, and the Influence of the Learning-Teaching Context on Approaches to Learning, Accounting Education: An International Journal, Vol. 6, No. 2, pp. 125-146.

Sundem, G.L. and Williams, D.Z. (1992). Changes in Accounting Education: Preparing for the Twenty-First Century, Accounting Education: An International Journal, Vol. 1, No. 1, pp. 55-61.

Taylor, I. (1997). Developing Learning in Professional Education: Partnerships for Practice, Buckingham: Society for Research into Higher Education and Open University Press.

Tinker, T. (1985). Paper Prophets: A Social Critique of Accounting, New York, NY: Praegar Publishers.

Van Rossum, E. and Schenk, S. (1984). The Relationship Between Learning Conception, Study Strategy and Learning Outcome, British Journal of Educational Psychology, Vol. 54, No. 1, pp. 73-83.

Van Rossum, E., Deijkers, R. and Hamer, R. (1985). Students' Learning Conceptions and Their Interpretation of Significant Educational Concepts, Higher Education, Vol. 14, No. 6, pp. 617-641.

Van Rossum, E. and Hamer, R. (1985). Learning: Qualitative Differences between Novices and Experts, paper presented at the Eleventh International Improving University Teaching Conference, State University of Utrecht, Netherlands, 2-5 July.

Watkins, D. and Regmi, M. (1992). How Universal Are Student Conceptions of Learning? A Nepalese Investigation, Psychologia, Vol. 35, No. 2, pp. 101-110. 